\title{
Bringing the 'formal' back in: Nur Otan, informal networks and the countering of elite instability in Kazakhstan
}

Rico Isaacs ${ }^{1}$

Originally published in Europe-Asia Studies, 65 (6) (2013): 1055-1079

\section{Introduction}

Scholarly understanding of Central Asian politics since the collapse of the Soviet Union has been dominated by reference to informal politics, practices and institutions. With some exceptions (Jones-Luong, 2002), the prevailing wisdom has been that informal rules matter (O’Donnell, 2006) and to 'make sense of political processes and outcomes in such contexts, paying attention to the formal institutions that are typically the focus of political scientists is inadequate; in addition—or instead—one must study informal institutions and interactions' (Radnitz, 2011). While informal politics occurs and operates in many different guises, its form in Central Asia has been characterised by informal networks of particularistic ties which are based on real and fictive kinship bonds that operate outside of formal officially sanctioned channels. Such networks have tended to produce forms of patronage, clientelism, corruption and bonds of personal loyalty. Typically these informal networks have been labelled 'clans' (Schatz, 2005; Collins, 2006). In Central Asia formal political institutions have been observed as largely ceremonial (Fumagalli, 2007:2). For example, 'constitutions have been written, elections held, parties established and systems of justice developed. In none of these countries, however, do these institutions operate as the primary means for conducting

\footnotetext{
${ }^{1}$ I am indebted to the Leverhulme Trust (Ref: SAS/30161) and the British Academy (Ref: SG101607) who provided funds which made the fieldwork for this research possible. I am also grateful to Gary Browning and Sarah Whitmore for reading an earlier draft of this article. All mistakes are solely those of the author.
} 
political activity' (Melvin, 2004: 127). The prevalence of informal politics is argued to have a corrosive effect on formal institutions (Stefes, 2006), while formal institutions in this postSoviet context are often described as a form of 'virtual politics' (Wilson, 2005). ${ }^{2}$ Nevertheless, formal institutions have continued to persist in Central Asian politics with little thought as to why. If informal institutions and practices are the main arena of political contestation, and responsible for the shaping of political outcomes, over and above formal institutions such as elections, constitutions and legal systems, why have the authoritarian presidents of the Central Asian Republics persisted with them? What benefits can formal institutions provide for the region's rulers? And how might they contribute to our understanding of the relationship between the formal and informal in Central Asia?

It is these principal questions this article intends to address through a case study of Nur Otan (Ray of Light Fatherland), the president of Kazakhstan, Nursulstan Nazarbayev's political party. The intention is to explore the role a political party, as a formal institution, can play in one of the authoritarian regimes in Central Asia, examine how a political party might interact with informal institutions and practices, and consider the implications of the role of political parties and their interaction with informal politics on regime stability and dynamics. To explore these issues the article utilises a two-part theoretical and conceptual framework. Firstly, it utilises the literature on formal and informal politics to examine their interaction in the case of Kazakhstan. Existing literature on the interaction between formal and informal politics concentrates of how informal politics can strongly affect the operation of democratic institutions, or the development of institutions in transitory regimes. Adding to the body of

\footnotetext{
${ }^{2}$ Wilson employs the term 'virtual politics' specifically in relation to the use of political technologies. The implication of his work, however, is that many formal institutions in the post-Soviet space are potentially 'hollow' and vacuous.
} 
work this article explores the interaction between informal and formal politics in a consolidated authoritarian regime. Secondly, it employs the literature on authoritarian regimes and formal institutions to theorise the different functions formal institutions, and in particular political parties can play in dictatorships. This discourse advocates that there are two primary functions political parties perform in authoritarian regimes: elite bargaining and mass mobilisation.

This article argues that Nur Otan undertakes a leading role in aiding elite stability vis-à-vis the fractious nature of competition between informal elite networks. With few exceptions (Jones-Luong, 2002; Ishiyama, 2008), much scholarship on Central Asia has focussed on the influence and prevalence of informal politics at the expense of formal politics. This work seeks to re-address that balance as well explore more closely how the formal and informal interact in the region. It illustrates that rather than the current assumptions that informal politics pervade formal institutions in Central Asia (Radnitz, 2011, Collins, 2006), by subverting and competing with them, formal institutions can instead act to stabilise the disruptive and capricious nature of informal politics and consequently support authoritarian regime stability. The extent to which the party can perform this function in the long-term, however, remains uncertain. Nur Otan's on-going existence is so reliant upon its connection to President Nazarbayev that once he departs the political scene the stabilising function Nur Otan plays is likely to diminish. Potentially this could create instability and bring the informal political factionalism the party envelops into the open. The case of Nur Otan in Kazakhstan reveals that formal institutions do have a role to play in regimes in which it is typically understood that power, decision-making and political relations are dominated by what is believed to be informal forms of political behaviour (patronage, clanism, clientelism, corruption etc). Additionally, the case of Nur Otan muddies the conceptual dichotomy 
between the formal and informal that exists in political science. Nur Otan's close relationship with its patron, the President of Kazakhstan, illustrates that the dividing line between what we understand as formal and informal is not so clear cut. Nur Otan is a party which lacks agency from the personalised rule of Nazarbayev and its preeminent position in Kazakh party politics stems from the informal preference it receives due to this position. As a party it is difficult to untangle its formal public position from the informal preference it receives. Therefore, in the case of Nur Otan it is difficult to see conceptually where the formal begins and the informal ends. The purpose of this article is not to provide an answer to this. Its aim is more modest and that is to reintroduce the study of formal institutions back into scholarship on Central Asian politics which in recent years has been dominated by a fixation on informal institutions, organisations and relations. However, at the same time, as reflected in the title of the article, it recognises formal institutions in Kazakhstan have to be understood in relation to the perceived dominance of informal networks, relations and behaviour.

The article proceeds firstly by conceptually unpacking the idea of formal and informal institutions, and the different ways in which scholars have proposed they interact. Secondly, the article then outlines the distinctiveness of the informal and formal in Kazakhstan and Central Asia more generally. Thirdly, the article explores the literature which examines the functions a political party and formal institutions more broadly play in dictatorships. Here it is argued that Nur Otan provides a modified elite bargaining benefit as it supports authoritarian presidential rule through aiding the alleviation of elite instability and generating instead cohesion and homogeneity amongst informal elite networks and lower level state employees. The fourth section concentrates on Nur Otan's role in this respect and explores the early antecedents of the party, the rise and fragmentation of informal networks, the use of Nur Otan to consolidate presidential power in response to political instability through the 
consolidation of pro-presidential parties and the synthesis between state and party positions, and the extent to which this proved successful. Lastly, the article addresses whether Nur Otan can contribute to regime durability in the long-term and how this case informs our understanding of the relationship between the formal and informal in Kazakhstan and beyond.

\section{Distinguishing Informal and Formal Institutions}

How do we best conceptualise, understand and distinguish between formal and informal institutions? From a neoinstitutionalist perspective institutions are 'the rules of the game in a society, or more formally, the humanly devised constraints that shape human interaction' (North, 1990: 6). Institutions, therefore, structure human interaction whether it is political, social or economic. They are typically the rules which guide behaviour and human interaction and as such deviation from those rules usually results in some form of sanction. The threat of sanctions, therefore, bind individual and collective bodies to the given rules and norms. This definition incorporates both formal and informal rules (Helmke and Levitsky, 2006). A distinction between formal and informal institutions is usually grounded in the notion of official codification. According to Lauth (2004: 69) 'informal institutions are institutions which are not formally codified in official documents (either in constitutions or laws)'. Distinct from formal rules 'they are not officially written down, nor are they enforced by legal recognition or the power of the modern state' (Grzymala-Busse, 2010: 312-13). Lauth's and Grzymala-Busse's definitions of informal and formal institutions will be applied in this article. At the same time it is useful to distinguish between informal institutions and other types of informal phenomena as they are not all the same. As Helmke and Levitsky have suggested, 'not all patterned behaviour is rule bound, or rooted in shared expectations about others behaviour' (Helmke and Levitsky, 2006: 6). Informal institutions appear in varying 
forms and it is important to dissemble their different manifestations because the different forms they take can produce different outcomes vis-à-vis formal institutions. For instance the notion of an informal institution has been used in a very general sense to characterize aspects of traditional culture, personal networks, clientelism, corruption, clan and mafia organizations, civil society, and a wide variety of legislative, judicial, and bureaucratic norms' (Helmke and Levitisky, 2003:7-8). Helmke and Levitsky suggest that such a broad conception is unhelpful and that we need to distinguish between informal institutions and other informal practice. They observe four phenomena that informal institutions should be untangled from: weak institutions, informal behavioural irregularities, informal organisations and culture (2006: 6-8). Lauth (2004) on the other hand argues that informal institutions appear more specifically as cilentelist structures (which can be divided into three sub-types: kinship, mafia and clientelist parties), corruption, threat perception and customary law (1122). The informal networks in Kazakhstan which are part of the subject matter of this article fall within Lauth's conception of an informal institution as a clientelist structure. What is clear from the above is that informal forms of politics appear in multiple forms, and as a consequence are capable of producing varying outcomes in diverse contexts and can interact in various ways with formal institutions. ${ }^{3}$

\section{The interaction between formal and informal institutions}

\footnotetext{
${ }^{3}$ Informal politics is understood and used in this article as a comprehensive term which encompasses all forms of political behaviour, relations and rules which exist outside of officially sanctioned channels. That is informal politics as a term takes under its umbrella informal institutions, organisations, and practices. Such forms of informal politics then tend to produce different types of informal behaviour such as corruption and patronage. As suggested by Lauth 'Informal politics include different variations of action, which do not necessarily have to be linked to institutions. Informal actions can either be based on rules or they can have spontaneous or erratic character' (Lauth, 2004: 73).
} 
In recent years scholars have paid significant attention to how formal and informal institutions interact (Grzymala-Busse, 2010; Koehler, 2008; Bratton, 2007; Levitsky and Way, 2006; Lauth, 2004). Interaction typically occurs in four ways. Firstly, informal institutions act to complement formal institutions 'they exist side-by-side and mutually reinforce and support each other' (Lauth, 2000: 25). For example, Fumagalli has argued that a combination of formal and informal institutions accounted for inter-ethnic stability in the Southern city of Osh in Kyrgyzstan. Fumagalli proposed that the absence of formal institutions in the early 1990s explains why inter-ethnic conflict occurred at that time. Since then the institutionalisation of formal institutions, most notably local government positions, acted to complement the informal institutions under pinning inter-ethnic relations in the region. It is this interaction between the formal and informal which Fumaglli suggests led to inter-ethnic stability in a region which had been prone to violence and conflict (Fumagalli, 2007:24-25). This thesis of course is notably and fully expunged by the outbreak of interethnic violence in Osh in June 2010. Nevertheless, Osh does provide an example of how the formal and informal can complement one another and produce political stability for a period of time, but perhaps further study is required to understand why such stability breaks down. A further example of a complementary relationship is in some aspects of informal customary law. Lauth suggests that folk traditions 'continue to belong to a type of customary law that can even be enforced in non-state or even partially state-controlled tribunals, as one can observe in many Western African countries' (Lauth, 2004: 79).

Secondly, there are accommodating informal institutions. This is when informal institutions can be "viewed as a "second best" strategy for actors who dislike outcomes generated by the formal rules but are unable to change or openly break those rules' (Levitsky and Way, 2003). For example, research has illustrated in the case of Costa Rica that the formal electoral law 
fails to promote constituency service as deputies are not allowed to stand for re-election. Political parties, therefore, informally incentivize their deputies to engage in constituency work as deputies are dependent on parties for any future political career outside the legislature. (Taylor, 1992:1071-1072). Thirdly, informal institutions are seen to compete with formal institutions. Clientalistic and particularistic structures produce a tendency to undermine formal institutions. For example, in Egypt, prior to the recent revolution, informal institutions were viewed as subverting the democratic electoral process (Koehler, 2008). Arguably prior to the 2011 uprising the 'informal distribution of power determin[ed] the fundamental rules of the political game' and this meant that formal electoral rules were manipulated and subverted to serve the interests of the Mubarak regime (Koehler, 2008:976). In Central and Eastern Europe it has been acknowledged that corruption and clientelism remain the main obstacles for establishing the rule of law, and thus, the consolidation of democracy (Guasti and Dobovsek, 2011). Fourthly, informal institutions can take on a substitutive role vis-à-vis formal institutions. For instance, in Eastern Europe it has been proffered that formal institutions remain weak but informal institutions work to substitute for such weaknesses. Political actors may possess desired outcomes which cannot be guaranteed through formal institutions. Instead they turn to informal institutions to ensure their preferred outcomes are met (Gallina, 2011).

Much of this prior scholarship has focused on the interaction between informal and formal institutions in relation to how this interaction impedes democratic consolidation or the functioning of formal institutions typically observed as fundamental to democracy. While Anna Grzymala-Busse (2010) has sought to analyse the interaction between the informal and formal in transitional regimes, few of these works have explored how the interaction between formal and informal institutions aid authoritarian regime stability. This account of Nur Otan 
reveals how formal institutions can stabilise authoritarian rule through mitigating the instability to authoritarian leaderships produced by competition between informal networks, and as such the interaction in this case is based on a complementary relationship.

\section{Informal and Formal Institutions in Kazakhstan and Central Asia}

Informal and formal institutions interact in all political systems. Indeed clientelism and patrimonialism are not limited to non-democractic or transitional regimes (Kitschelt and Wilkinson, 2007). Informal norms of behaviour can often subvert formal institutional rules in entrenched liberal democracies too. For instance, in advanced democracies, despite women 'formally' possessing an equal opportunity to obtain political office, they are often 'informally' inhibited by the historical dominance of patriarchy (Millet, 1970). It is important, therefore, to distinguish the types of informal politics which exist in Central Asia and Kazakhstan from the forms which occur in all political systems.

Informal political phenomena in Central Asia has been characterised through the notion of 'clan politics' (Collins, 2006; Starr, 2006; Schatz, 2005). Clans are organisations which are informal networks of particularistic ties which can be based on actual or fictive kinship bonds. These informal networks are understood to be the arena in which real political power and decision-making occurs, not the formal institutional realm. According to Kathleen Collins, 'clan politics creates an informal regime, an arrangement of power and rules in which clans are the dominant social actors and political players; they transform the political system. Clan networks, not formal institutions and elected officials, hold and exercise real power' (Collins, 2006: 3). Clan politics is not particular to Central Asia. As mentioned above, these types of informal networks exist in advanced democracies. In the UK for instance we could observe numerous political dynasties as manifestations of informal political networks 
(e.g. the Benn Family). In the United States there are a number of cases of informal family networks who through their connections gain privileged access to resources and political positions beyond which an ordinary citizen might obtain (Kennedys, Bushes etc.). The difference in Central Asia, however, is the extent to which these informal networks penetrate and at times displace formal institutional rules and norms. In the US and UK these family clans largely abide by the formal institutional rules and accept the loss of political power on the basis of those rules. In Central Asia such acceptance and commitment to meaningful formal rules is not evident. Consequently, clientelism, patronage and corruption have often been the product of the dominance of these informal clan networks in the region to an extent which would not be permissible in advanced democracies (even though it does occur in such systems from time to time).

Some scholars assert there is an overemphasis on the familial kinship based identity of these informal clan networks in Central Asia and that instead they are situated on regional identities constructed by the Soviets elites of the1920s and 1930s (Jones Luong, 2002; Cummings, 2000). Recent work, however, denotes the delineation along either clan or regional lines underestimates the complexity of these networks (Tunçer-Kılavuz, 2009, Gulette, 2007, Radnitz, 2005). These informal networks are multifarious they 'draw on various loyalties including ties of family, friendship, work, education, and patron-client relationships. They are neither purely regional nor purely clan-based' (Tunçer-Kılavuz, 2009:323). Moreover, there is variation across the region (Ilkhamov, 2007) with some suggesting that 'blood ties' are more evident in Kazakhstan (Schatz, 2005) where as in Uzbekistan and Tajikistan 'lineage identity does not play such an outstanding role... In Uzbekistan what are often meant by 'clans' are very loose coalitions composed by various 
types of allegiances, including kinship, friendship, patron-client, client-client partnerships' (Ilkhamov, 2007: 70).

In the case of Kazakhstan, while some scholars have played up tribal identification based on kinship (Schatz, 2005), these informal networks have often been labelled as 'lobbying' or 'influence' groups (Satpayev, 1999. 2007; ECPRAST, 2005). This characterisation of informal networks illustrates that while some of these networks are based on familial tribal kinship bonds (Khlyupin, 1998) what typifies them is their concentration around economic interests (Junisbai, 2005, 2010). Dosym Satpayev, a prominent analyst in the country, has argued that 'one reason defines their behaviour, economic interests: only economic interests, no tribes, no other factors. The most important factor is economic interests' ${ }^{4}$ Additionally, in 2007 much of our understanding of how clan politics underpined Kazakh politics was blemished when Nazarbayev moved to marginalise his daughter (and presumed successor) Dariga Nazarbayeva and her husband Rakhat Aliev from both their political and economic interests (see below). What is clear, however, is that these particularistic networks through which access to economic and political resources are channelled largely underpin the political system and are the main arena for political contestation.

Power and decision-making in Central Asia is mostly personalised. Perhaps with the exception of Kyrgyzstan post the 2010 revolution, the presidents of the Central Asian Republics all lead personalist authoritarian regimes as understood through the Weberian lens of non-rational forms of political authority (Weber, 1978). A personalist-authoritarain regime

\footnotetext{
${ }^{4}$ Interview with Dosym Satpayev, Political Analyst, 28 February 2007, Almaty, Kazakhstan
} 
is understood as relying on 'informal, and sometimes, quite unstable personal networks sometimes based on kinship, ethnicity or region - within which particularistic favours are exchanged for support' (Geddes, 2003; 53). Islam Karimov in Uzbekistan, Nursultan Nazarbayev in Kazakhstan, Gurbanguly Berymukhamyedov in Turkmenistan and Emomalii Rahmon in Tajikistan possess the power to assign most public positions, including regional governors, law enforcement bodies, courts, the cabinet and usually some members of the Senate (except in Turkmenistan where a second chamber was abolished in the constitutional amendments of 2008). In turn this power of patronage generates loyalty from state clients and other elites as officials are willing to prove their loyalty to the president by undermining formal institutions and formal rules in an effort to impress and meet the needs of their political patron. The Central Asian presidents are able to rely on personal loyalty and extensive patronage networks to influence and foster a political system to suit their personal preferences. Consequently, formal institutions such as elections, the courts and constitutions are engineered to favour a positive outcome for the incumbent presidents. As Neil Robinson has argued when addressing the role of informal politics in the post-communist space, 'informal practices such as corruption, clientelism and patronage in post-communist polities... and other forms of sub rosa bureaucratic malfeasance can be so important to the operation of post-communist political and economic systems that they sometimes crowd out formal systems of governance and redistribution and make them meaningless' (Robinson, 2007: 1217). A liberal-democratic conception of formal institutions may conclude that their operation in the post-Soviet space is meaningless given the dominance of informal politics, yet formal institutions are meaningful in other ways for the region's authoritarian leaders.

In Kazakhstan the personalist system is based on a series of dyadic and interconnected patron-client relationships in what has been described by Kazakh political scientist Nurbolat 
Masanov as a 'protectorship-client' system (Masanov, 2000). The relationships are used for the 'bilateral exchange of resources, information, mutual help, services and other responsibilities' (Masanov, 2000). A by-product of the 'protectorship-client system' is the development of informal networks who engage in competition for access to resources. Nazarbayev has acted as the chief mediator and arbitrator in the competition over resources by these informal networks (Khlyupin, 2000). Consequently, Nazarbayev resides over a political system where personal loyalty is fundamental, access to appointments and resources are linked to access to the president, and a repercussion the system is systematic corruption. In effect it is the person of the president which is important not the impersonal office of the presidency (Borisova, 2005).

Despite scholarship focusing on the role of informal networks and their seeming importance in terms of subverting and competing with formal institutions, formal institutions persist in the region and are utilised by the region's authoritarian leaders. Constitutions, legal systems, elections, legislatures and political parties all provide a veneer of democratic respectability for the region's presidents even if they are engineered and manipulated by the authorities. For example, the constitutions in Kazakhstan and Uzbekistan have been often been revised and amended to suit the political needs of Nazarbayev and Karimov. In 2007, the government of Kazakhstan, through the State Commission for Democratic Reforms, recommended the constitution was altered to change the two-term limit for the presidency. It was amended so there would be no limit to the number of times the first president of the Republic of Kazakhstan (Nazarbayev) could stand for re-election (Duvanov, 2007). Elections have been used in all of the Central Asian states to illustrate on-going popularity and legitimacy for the incumbent and assists in establishing an aura of invincibility (Magaloni and Kricheli, 
2010). ${ }^{5}$ So despite power and decision-making being channelled through informal institutions and behaviour such as the informal networks (clans) and personal loyalty to the president, the rulers of Central Asia still utilise formal institutions, and how they do so, and the benefits formal institutions can provide for authoritarian rulers, is discussed below.

Before moving on however, it should be noted that a clear dichotomy between the informal and formal is not always apparent, at least not in empirical terms. Jones Luong (2002), for example, has argued that regional identities, based on the formal institutional divisions constructed by the Soviets, transformed pre-existing informal social and cultural bonds 'infusing them with a new social, political and economic meaning'. The Soviet state thus created incentives for individuals to shift their social and political identities from pre-existing tribal and religious identities to "Soviet-inspired" ones and to personally invest in these identities over time' (Jones Luong, 2002: 63). Evidently the formal and informal can overlap and become infused. Similarly, as will be demonstrated, in the case of Nur Otan the interaction between formal and informal politics is ambiguous. Indeed rather than being undermined and pervaded by informal institutions such as informal networks, and the patronage and clientelism which emerge from them, Nur Otan complements informal networks by playing a role in stabilising their intractable nature. This in turn has weakened threats to Nazarbayev's personalist rule. The implication of the empirical overlapping of the formal and informal is that the conceptual dichotomy is not as clear and elegant as it appears on the surface.

\footnotetext{
${ }^{5}$ In the 2007 Uzbek presidential election according to the official results Islam Karimov received 90.77 per cent of the vote. Similarly in the 2011 Kazakh presidential election Nazarbayev was awarded 95.55 per cent of the vote.
} 


\section{The Role of Formal Institutions in Authoritarian Regimes}

The idea political parties, and other formal institutions typically associated with democracies (e.g. elections), have an important function in relation to providing benefits for authoritarian regimes is not new (Magaloni and Kricheli, 2010; Gandhi, 2008; Brownlee, 2007; Gandhi and Przeworski, 2006; Geddes, 2006; Lust-Okar, 2005; Pempel, 1990; Wintrobe, 1998). The premise of this literature is that formal institutions provide important functions which serve the interests of incumbent authoritarian leaders. This body of work has identified a number of benefits formal institutions supply for dictators. In particular formal institutions are invested with the capability and capacity to proffer greater authoritarian regime stability and longevity. Jennifer Gandhi and Adam Przeworski make the case that legislatures can be crucial for a dictator's strategy to co-opt and provide policy concessions to opposition elites (2006: 3-4). With specific reference to the role of political parties, it has been argued that authoritarian regimes which rely on parties to rule last longer than those which do not (Geddes, 2006). Beatriz Magaloni and Ruth Kricheli have proposed two broad roles parties perform in non-democratic regimes: 'a bargaining function, whereby the dictator uses the party to bargain with the elites and minimise potential threats to their stability; and a mobilizing function, whereby dictators use the party machine to mobilize mass support' (2010: 124-126). Inherent within these two broad functions are a number of sub-functions. It is not the scope of this article to rehearse and explain all these different functions in-depth, as this has been achieved elsewhere (Bader, 2011; Magaloni and Kricheli, 2010 and Geddes 2006). Nevertheless, it is worth briefly traversing them and outlining not only those relevant to Nur Otan, but also how Nur Otan demonstrates an additional role a political party can fulfil in light of countering instability generated by competition between informal networks. 
In relation to elite bargaining and co-option, political parties can serve the interests of autocrats as a channel to distribute economic benefits and transfer rents to opposition elites to gain their loyalty (Gandhi and Przeworski, 2006). In the case of many authoritarian systems rents are given out 'and the dictator received political support or money payments in turn' (Wintrobe, 1998: 153). Using a political party to distribute rents in this manner between elites assists in generating loyalty to the regime and binding in potential challengers. Autocrats can also use parties to 'broaden their appeal by making policy concessions in a direction favoured by potential opponents' (Magaloni and Kricheli, 2010: 126). However, it is often the case that the legislature, and thus consequently the ruling party, is not the arena in which policymaking and more importantly decision-making occurs (Blaydes, 2009). Nur Otan similarly is not an institution which truly has the ability to make policy concessions to oppositional elites. Power and decision-making lies not with the party and neither with the legislature but with the presidential administration. While the presidential administration, and consequently Nur Otan, may adopt policy advocated by opposition parties, it is not clear whether this is undertaken to co-opt opposition elites or perhaps to broaden the president's constituency by embracing some of the popularist polices of opposition parties such as OSDP-Azat (Nationwide Social Democratic Party- Freedom) and Alga (Forward). As one former Akim (governor) and opposition leader argued 'parties do not strictly influence decision-making but nowadays the opposition is a leader of public opinion. In terms of affecting public opinion the opposition is ahead of the government on this'. ${ }^{6}$ One further function highlighted in the literature is 'using the ruling party in order to make intertemporal power-sharing deals with potential elite opponents' (Magaloni and Kricheli, 2010: 127). A political party can control access to privileged political positions. Therefore, potential challengers are more likely to

\footnotetext{
${ }^{6}$ Interview with Galymzhan Zhakiyanov, Chairman of the Public Foundation 'Civil Society', 10 January 2007, Almaty, Kazakhstan.
} 
support the regime if they gain access to revenue paying positions. Over the long-term this binds elites into the regime providing them with a share and stake in power and resources. However, the 'credibility of the power-sharing deal crucially depends on the party's ability to effectively control access to political positions and on the fact that the party can be expected to last into the future. A dictator will possess an interest to uphold a system of credible power-sharing with his ruling clique to make his life less vulnerable to conspiracies, military coups, and violent rebellions' (Magaloni, 2008: 716).

Under the rubric of building mass support a political party can support an authoritarian regime by being the mechanism through which privileges and resources are distributed among the wider population. Autocratic rulers look to a dominant party to 'build mass support for themselves and their policies by both delivering benefits and teaching ordinary citizens the regime view of the world' (Geddes, 2006:12). As Magaloni and Kricheli (2010) argue 'when they are well institutionalised ruling parties should be understood as giant patronage systems that give citizens a vested interest in the perpetuation of the regime' (128). The Communist Party of the Soviet Union (CPSU) performed this distributive function expertly in dolling out jobs, privileges and luxuries not available to ordinary citizens unless they proved loyal and well-connected to the party (Hough and Fainsod, 1980). A ruler can rely on a formal institution to structure and provide cohesion to their patronage networks, binding elites to their leadership and fostering loyalty from the wider population. Rulers are able to bind both elites and ordinary citizens to the regime by the distribution of rents to those who are loyal and by punishing those who withhold their loyalty (Magaloni and Kricheli, 2010). To this affect a party can evolve as an 'instrument of punishment' which can be called on to either withdraw benefits and rents or initiate corruption investigations against 
individuals and organizations that are not proving loyal to the regime. ${ }^{7}$ In order to guarantee the loyalty of citizens the regime is required to monitor their activities. Maintaining such surveillance necessitates a strong and active party organization which can monitor and sanction citizens accordingly. Magaloni and Kricheli also point to the important role parties play in ensuring large electoral turnout and votes for the ruler or his party. Ensuring both a high electoral turnout and votes for the ruler generates 'an image of invincibility that works to dissuade potential elite challengers' thus promoting regime stability and longevity (Magaloni and Kricheli, 2010: 129).

Does Nur Otan serve any of the functions explored above for the Nazarbayev regime? When the party emerged in 2006 some analysts suggested that Nur Otan took as their model dominant parties such as the People's Action Party (PAP) in Singapore or the Institutional Revolutionary Party (PRI) in Mexico (Grosin, 2006). These parties are typified as 'dominant parties' due to being 'so electorally powerful as to render it unlikely to be defeated in the foreseeable future' (Suttner, 2006:278). As Bader has argued when referring to dominant parties in the former Soviet space including Nur Otan, they do contribute 'to the marginalization of real and potential opposition, but do not serve as a major channel for the career advancement of elites and do not significantly involve the populations of the countries (Bader, 2011: 8). However, this does not mean Nur Otan is inconsequential. Rather the party does provide a role in relation to the cooption of the opposition and potential challengers to the regime, but not necessarily as outlined in the existing literature. While the party has been used to solicit elite cooperation and loyalty there is no evidence to suggest that it achieves

\footnotetext{
${ }^{7}$ I am indebted to Assel Rustemova for introducing this term to me in relation to Nur Otan. Similarly, Magaloni and Kricheli (2010) posit the idea of a dominant party being part of a 'punishment regime' where a party acts to either hand out or withdraw resources on the basis of loyalty to the regime.
} 
this through being the channel through which rents and resources are distributed. Conversely, there was an example where a local Akim solicited money from local farmers for the right to lease land which then directly went to fund the coffers of Nur Otan. Sergei Erin the Akim of the Esil raion in the Akmola oblast was found guilty of extorting money from a local farmer for the lease of some land. The money was then transferred to the local Nur Otan branch. This apparently occurred with other entrepreneurs in the region too (Khabiev, 2011). This is revealing as it illustrates that the power to extort and distribute resources lies with local authority figures and not the party itself. The distribution of rents does not emerge from the party but from the personalised regime as district Akims are appointed by regional Akims who are appointed by the president.

The protectorship-client system that exists in Kazakhstan sees elite groups compete for access to resources and positions. President Nazarbayev arbitrates and distributes these rents, not the party. Instead the role of the party is to play a role in assuaging the instability and fall out which was a product of competition between these informal networks. As before, Nur Otan does not possess the autonomy or agency to offer policy concessions to opposition elites, and similarly the party is not necessarily the arena in which power-sharing deals take place. As Bader (2011) has observed, many Nur Otan deputies in parliament previously held low to mid level public positions and therefore hardly represent high-level elite officials a ruler may be in fear of and who need placating through some power-sharing deal. Rather the party as a formal institution exists to institutionalise elite support for the president and to mitigate the unstable effects of competition between informal political networks.

Nur Otan does act to mobilise political support, but again how it achieves this diverges from the functions identified in the existing literature. The party is part of a 'giant patronage 
system' as envisaged by Magaloni and Kricheli (2010) but there is little evidence to suggest the party is the entrance point for ordinary citizens to gain access to privileges and positions. Rather access to public positions remains the prerogative of important state officials (such as Akims) not the party per say (even if those state figures are members of the party). Rather the party possess a far broader role in terms of promoting mass support for the regime. The party is instrumental in the legitimisation of Nazarbayev's power by developing and articulating homogeneity of opinion regarding the centrality of his leadership to the prosperity of the country. This article does not explore the nature of Nur Otan's role in terms of mass mobilisation, particularly in terms of promoting legitimisation and articulating homogeneity of opinion regarding Nazarbayev's rule as this has been covered elsewhere (Isaacs, 2011: 130-155). Instead below is an analysis of how Nur Otan emerged as part of a process to provide elite stability. If we understand political stability as 'the extent that members of society restrict themselves to the behaviour patterns that fall within the limits imposed by political role expectation' then elite stability in an authoritarian regime is the extent to which both high-level and low level elites remain within the limits and expectations of their role as members of the regime and state (Ake, 1975: 273). Deviation from expected norms of behaviour by publicly criticising the operation and conduct of the ruler and their regime, can amount to a threat to the stability and durability of the authoritarian regime. The sections below explore the extent to which the competition between informal networks in the personalist-authoritarian regime of Nazarbayev represented a threat to the stability and durability of the regime and the role that Nur Otan played in alleviating that threat.

\section{Nur Otan, Informal Networks and the Countering of Elite Instability}

Antecedents to Nur Otan 1991-1999 
A political party which functions among other things to stabilise political elites and co-opt and marginalise opposition to an incumbent regime has a long history in Kazakhstan: the Communist Party of the Soviet Union (CPSU). Indeed the dominant experience Kazakhstan has to draw upon for developing political parties in the post-Soviet period remains the Soviet era Communist Party. Historical institutionalism denotes that prior institutional antecedents set the norms and rules which become difficult to diverge from (Thelen and Steinmo, 1992; Hall and Taylor, 1996). Given Nur Otan's dominance of party politics in Kazakhstan, it is often viewed as the successor, if not ideologically then organisationally, to the CPSU and gives some credence to a historical institutionalist perspective in the case of Kazakhstan. ${ }^{8}$ There was, however, no straightforward transition from the Soviet era Communist Party of Kazakhstan to Nur Otan. Rather the process was protracted and fragmented.

The diminishment of the CPSU's powers in the late Soviet period saw a power structure emerge which was more personalised and based on the newly created position of the president rather than the institutionalised party. Similar to events in Russia, after independence President Nazarbayev moved quickly to dissolve the Communist Party of Kazakhstan, but immediately attempted to form a party out of its rubble which could perhaps provide benefits and support his leadership. After the dissolution of the Kazakhstan Communist Party in September 1991 the president backed and supported the establishment of a reformist Socialist Party of Kazakhstan (SPK, 1992; D’yachenko, Karmazina, and Seidumanov, 2000). The party saw a large number of sitting deputies in the Kazakh Supreme Soviet switch from the Communist Party to the newly formed SPK (Ayaganov, Baimagambetov and Zhumanova, 1994: 14). The SPK, however, proved unreliable in supporting presidential rule and policies. The party consisted of deputies in the Supreme

\footnotetext{
${ }^{8}$ As of the 2012 parliamentary election Nur Otan holds most of the seats in the Mazhilis with a small proportion being held by two other pro-presidential parties)
} 
Soviet who had vested interests in state owned enterprises and were anxious of Nazarbayev's economic reform programme which threatened their hold on such interests. Subsequently, in 1993 the party collectively withdrew its support for Nazarbayev and moved into opposition (Isaacs, 2011) using the legislative arena to put a brake on the president's economic reform programme (Olcott, 2002).

With the SPK emerging as centre of opposition a new party emerged around the president: the Union of People's Unity of Kazakhstan (SNEK). Evidently, this party was an effort by figures close to the president to establish a distinctive political party which could support and serve the interests of Nazarbayev's policy programme against the opposition centred in the Supreme Soviet. The party attracted the interest of government ministers including the Deputy Prime Minister Kuanish Sultanov and a number of elites who would go on to have important careers in the government and other political institutions such as Marat Tazhin, Serge D'yachenko and Kenzhegali Sagadiev (Ayaganov, Baimagambetov and Zhumanova, 1994: 37; Babak et al, 2004: 175-6). While SNEK won 30 seats (of 177) in the parliamentary election of 1994, and were thus the largest party in the parliament, the legislature remained a thorn in the side of the president due to their resistance to his reform programme. Arguably, SNEK was formed to mitigate the institutional conflict which appeared during this period so as to ensure the president could face off opposition from the new parliament (now called the Supreme Kenges) (Isaacs, 2010). SNEK, however, did not succeed in tempering legislative opposition. Consequently, the president turned to re-draw the constitutional map. $\mathrm{He}$ dissolved the parliament, strengthened his constitutional powers and established a new institutional landscape in the shape of a new bi-cameral parliament (the Mazhilis and the Senate) and a new presidentially appointed body called the Assembly of Peoples of Kazakhstan (ANK); an institution intended to represent all peoples and ethnicities in the 
country (Konstitutsiia Respubliki Kazakhstan 1995, 2006). During this period of institutional change SNEK re-named itself as the Party of People's Unity of Kazakhstan (PNEK) and proved a key vehicle in coalescing political forces around the president in his push for stronger constitutional powers in 1995 . The party in its program explicitly stated that its 'mission is to provide support for the course of reforms conducted by the president of the Republic of Kazakhstan, Nursultan Nazarbayev' (Buluktaev, D’yachenko and Karmazina, 1998). In the parliamentary election of 1995 PNEK obtained 24 (of 67) seats in the more slim-lined Mazhilis. PNEK, however, during this period was not a dominant political force. There were a number of other parties represented in parliament. Some such as the Democratic Party of Kazakhstan and The Party of Revival of Kazakhstan were broadly pro-presidential; others such as the Peoples Congress Party were considered a loyal and constructive opposition, while others such as the reconstituted Communist Party were a more straightforwardly belligerent form of opposition. Doubtlessly PNEK existed to try and provide the president with a majority of support in the parliament - which to an extent it did. Yet, the party was never an arena where decision-making took place or where real power laid. The party was not a direct institutional replacement for the CPSU where elite bargaining, career advancement and the distribution of privileges and resources took place. PNEK was dissolved in 1999 along with a number of other pro-presidential parties into Otan (Fatherland) (D’yachenko, Karmazina, and Seidumanov, 2000: 356-7).

Nur Otan succeeded in the role of being a personalist party, where perhaps SNEK and PNEK were less successful, due to the president being in a much stronger position by 1999. By this point the president had managed to subdue the legislature (and PNEK and SNEK played a role in this), win presidential elections (in 1999 and 2005) and gain more political control over the periphery by appointing national elites to provincial positions (Cummings, 2005). 
Therefore, by 1999 a context emerged in which a personalist party dedicated to the policies and preferences of the incumbent leader could gain a hold of the elite and the wider state apparatus, and acquire the support of the public due to the strength of the president's position.

As discussed above, the post-95 period saw the extensive personalisation of the political system based around Nazarbayev. The concentration of powers gave the president greater control of appointments across the political system. State officials were aware they 'had been selected by the president personally and served his political interests' (Masanov, 2000). Emanating from this was the formation of a 'protectorship-client system gravitating to oligarchic forms with a supreme patron on top of the power pyramid, namely the president of country' (Masanov, 2000). This highly personal form of political power proved greatly destabilising as it led to a process of elite fragmentation where some of the informal networks which relied on the president's patronage felt they were being sidelined at the expense of those networks which were associated to the president by kinship. Otan and then Nur Otan emerged in response to the process of elite fragmentation to mitigate and provide durability for Nazarbayev's authoritarian regime.

\section{Elite Fragmentation}

A consequence of both the construction of a personalist 'protectorship-client' system, and the privatisation process in Kazakhstan from the mid 1990s onwards, was the emergence of influential elite networks competing for access to, and command of, former state enterprises. These groups took the form of various 'influence groups' which took control of key financial and industrial holdings (Satpayev 2007, Junisbai, 2010). Some groups were linked to the president by kinship including the group led by the president's daughter, Dariga Nazarbayeva, and her husband Rakhat Aliev while Nazarbayev's second son-in-law Timur 
Kulibayev also has his own group. Other groups not connected to the president by kinship ties also flourished, most notably the group led by Mukhtar Ablyazov, a former Energy Minster, Vladimir $\mathrm{Ni}$, a businessman and close confident of the president who made his wealth in light metal mining operations, and the Eurasian National Resource Corporation (ENRC) led by Aleksandr Mashkevich, Patokh Chodiev and Alijan Ibragimov (Satpaev, 2007). These groups were seen as the central political actors in Kazakhstan (Kaernet, H. et al, 2008; Satpayev 2007; Khlyupin, 1998) and their prominence is explained by weak democratic institutions, such as parties, elections and non-elected Akims (Junisbai, 2010:242). ${ }^{9}$ The importance of these 'influence groups' illustrates how 'informal networks' are viewed as having played a significant role in policy and decision-making, rather than the officially sanctioned channels of the government, legislature and political parties.

As these groups emerged Nazarbayev acted to mediate and arbitrate their interests. Consequently, some groups not connected to the president by kinship felt marginalised in the struggle for former state enterprises. The increasing influence, in particular, of Aliev and Kulibayev, saw other groups frustrated by their lack of access to new resources (Junisbai and Junisbai, 2005; Junisbai, 2010). According to one senior political figure, it was clear 'Aliev was gaining too much power and accruing too many business interests'. ${ }^{10}$ This led to several waves of elite fragmentation, the outcome of which was that leading members of the government and business openly challenged the president creating an atmosphere of regime instability. The first wave occurred in 1998 when former prime minister and architect of

\footnotetext{
${ }^{9}$ This article will not detail in-depth the configurations of these groups and which resources they mange as this has been covered expertly elsewhere (Junisbai, 2010; Kaernet, H. et al, 2008) and is not the primary focus of this article.

${ }^{10}$ Interview with senior Ak Zhol official, 18 January 2007, Almaty, Kazakhstan.
} 
Kazakhstan's privatisation programme, Akezhan Kazhegeldin, openly criticised the president and moved into opposition. Kazhegeldin lambasted the operation of Nazarbayev's regime. It represented for one leading political analyst in Kazakhstan the first time 'a high-ranked official expressed his ambitions and for the first time made the big politics public'. ${ }^{11}$ In other words, it was the first time the closed politics of informal inter-elite competition became public. Despite announcing his political ambitions by establishing a political party, the Republican People's Party of Kazakhstan (RNPK), and proclaiming his intention to run for the presidency in 1999 (Olcott, 2002: 119-20), Kazhegeldin found himself discredited by a concerted campaign led by the authorities accusing him of tax fraud and money laundering. It is claimed that in 1998 a special team was established on the orders of the head of the KNB Alnur Musaev, a close associate of Rakhat Aliev, to liquidate the activities of Kazhegeldin and investigate his economic interests. ${ }^{12}$ Due to the pressure of the investigation into his financial dealings Kazhegeldin left Kazakhstan and moved into exile, firstly in Moscow and then Europe. In September 2001 he was convicted in absentia and sentenced to ten years. The RNPK have always maintained the charges were politically motivated (RNPK, 2001).

The most notable wave of elite fragmentation was the emergence of the Democratic Choice of Kazakhstan (DCK), an association of leading business (including Ablyazov and Galymzhan Zhakiianov, Akim of Pavlodar Oblast) and government elites (including many senior ministers) who came out in opposition to the increasing influence of members of Nazarbayev's family in 2001 (Chebotarev, 2006). This article is not the place to discuss indepth the events of 2001 as they have been dealt with elsewhere (Junisbai and Junisbai, 2005;

\footnotetext{
${ }^{11}$ Interview with Yevgenni Zhovtis, Director of Kazakhstan International Bureau for Human Rights and the Rule of Law, 29 January 2007, Almaty, Kazakhstan

12 Taszhargan, June 282007.
} 
Chebotarev, 2006). The conflict between the groups began intensifying as Aliev used his position as deputy head of the KNB (security services) to take control of some of Ablyazov's business including Turan Alem Bank while managing a portfolio of media assets such as the State TV channel Khabar and the newspaper Karavan (Junisbai and Junisbai, 2005: 380). One of the leaders of the DVK movement has recalled how 'Aliev was openly against some of the representatives of Kazakhstani business...and began taking over other people's companies'. ${ }^{13}$ In the view of one Kazakh analyst Aliev 'managed to concentrate in the hands of a significant part of their political, informational, administrative and penal-power resources of the State' (Kadyrov, 2007). DCK, therefore, emerged appealing to the president to protect leading elite figures against the arbitrary actions of state enforcement bodies and members of his own family (Serdalina, 2001). A number of different political parties emerged from the establishment of DCK each representing varied informal networks that dispersed from the ruling group and this essentially posed a threat to the political homogeneity of the personalist regime Nazarbayev had been constructing since 1995 . This includes Ak Zhol (Bright Path), Nagiz Ak Zhol (True Bright Path), later called Azat and Alga (Forward).

It is possible to see two further waves of fragmentation. The first was in 2004 when Zamanbek Nurkadilov a popular figure in the Southern regions of the country, former Akim of Almaty and Emergencies Minister openly criticised the president accusing him and his family of corrupt practices (Respublika, 2004). ${ }^{14}$ In the same year Zharmakhan Tuyakbai,

\footnotetext{
${ }^{13}$ Interview with Galymzhan Zhakiyanov, Chairman of the Public Foundation 'Civil Society', 10 January 2007, Almaty, Kazakhstan.

${ }^{14}$ Nurkadilov joined forces with the opposition party Ak Zhol but in November 2005 he was found dead with two gunshot wounds to the chest. The authorities declared it was a case of suicide but many in the opposition
} 
deputy leader of Otan (Fatherland), and speaker of the Mazhilis publicly criticised the conduct of the elections in 2004 and entered the opposition. Tuyakbai was the opposition's unified candidate for the presidential elections in 2005 under the loose public association For a Just Kazakhstan (FJK). The second instance was Rakhat Aliev's public ousting from Nazarbayev's inner circle. In 2007 Aliev had charges brought against him for his involvement in the kidnapping of two senior directors of Nurbank, one of Kazakhstan's leading banks. The president personally ordered the Prosecutor General and the Minster of Internal Affairs to conduct 'a detailed investigation of these criminal charges without regards for positions of privilege'. ${ }^{15}$ Nazarbayev's decision to cast Aliev out from his political circle surprised observers, as the prevailing assumption was that politics in Kazakhstan was about 'the family'. ${ }^{16}$ Instead the president was now insuring his rule at the expense of the political ambition and clout of his own family. ${ }^{17}$

Elite fragmentation demonstrates the turbulent nature of the personalised regime that had developed in Kazakhstan since independence. Members of the elite dissatisfied by the way resources were distributed effectively challenged the rule of the president by making public their disaffection and establishing political parties to support their efforts of obtaining public office. It was largely in response to this intractable context that Nur Otan emerged providing the president with the benefit of greater elite homogeneity and stability. Nur Otan succeed where its predecessors failed due to the context of presidential consolidation which had been

\footnotetext{
argue it was politically motivated, claiming Nurkadilov was about to produce documentary evidence proving corruption at the highest levels of the government, including Nazarbayev. See Respublika, 12 March 2004.

${ }^{15}$ MVD RK: K ugolovnoi otvetstvennosti privlekaetsia Rakhat Aliev, www.zonakz.net, 23 May 2007.

${ }^{16}$ Interview with NGO official, 2 November 2006, Almaty, Kazakhstan.

${ }^{17}$ Rossiiskiye Vesti, No 29, $6^{\text {th }}$ September 2007.
} 
developing since 1995 onwards after the introduction of a constitution granting greater executive powers to the presidency and in particular after 1999 when Nazarbayev won the presidential election. This highlights the extent to which the party is reliant on the president and his power base and that their dominance of the legislature and the party system stems directly from this. Consequently, Nur Otan has limited independent agency from the president. This is not to render meaningless the role Nur Otan plays for the president in particular in relation to countering the elite instability generated by elite fragmentation.

\section{Nur Otan: countering elite instability}

Nur Otan played a role in delivering elite stability in two ways. Firstly, it bound in informal networks and minimised the ability of independent actors to compete politically with Nazarbayev. Secondly, it has enabled wider homogeneity of the state apparatus as public employees were cajoled into joining the party. It paved a way for the majority of state employees to be bound and fused with the personalist regime of Nazarbayev.

To counter the instability of elite fragmentation Nazarbayev moved to concentrate his political resources and power. This included the concentration of economic resources (the State Holding Company Samruk-Kazyna), further institutional amendments (a new law on political parties in 2002 and further constitutional amendments in 2007 which ostensibly were introduced to give more power to parliament but in effect consolidated power in the presidency) and the concentration of political supporters into a single institutional form: the political party Nur Otan. Nazarbayev created Otan in 1999, just after his successful reelection as president. Despite dominating the 1999 and 2004 elections the party and the president still had to contend with political parties which represented the interests of other 
elite groups, most notably Asar (All Together) representing Aliev and Nazarbayeva, the Civil Party (GPK) representing the interests of Aleksandr Mashkevich and the ENRC, and Democratic Choice of Kazakhstan $(\mathrm{DVK})^{18}$ which represented Ablyazov. Despite both Asar and GPK being pro-presidential parties the competition between them and Otan during the 2004 parliamentary election was intense. The leader of GPK at the time, Azat Peruashev, pointed to this competition noting that 'leaders from the Otan party called me up and said "deal with your candidate in the region - he is trying to compete with the Otan candidate'. They thought we would support the Otan candidates and not our own'. ${ }^{19}$ The electoral competition served as a forum for these elite groups to compete for access to power, which in turn increased their ability to access economic resources. Nazarbayeva despite being the president's daughter was viewed as a powerful independent force with her party Asar. She often made comments regarding democratic reform, while Aliev himself admitted he was angling for the presidency.

In 2006 Nazarbayev achieved party-political consolidation by forcing through a merger between Asar, GPK and Otan, thus creating the super pro-presidential party, Nur Otan. The merger was a forced one for some in GPK and Asar; Azat Peruashev stated that he 'was against the mergers, from an emotional point of view, and also from the point of view of how

\footnotetext{
${ }^{18}$ DVK was an opposition party allegedly funded by Ablyazov. It competed in the 2004 parliamentary election in an electoral bloc with the Communist Party. They received only 3.4 per cent of the vote. A few months later towards the end of 2004 the party was liquidated by a court in Almaty on the grounds the party was responsible for undermining the social harmony, political stability and the national security of the state, due to encouraging people to undertake actions of civil disobedience after what they felt were the falsified parliamentary elections of 2004 .

${ }^{19}$ Interview with Azat Peruashev, former leader of the GPK and current leader of Ak Zhol, 18 February 2007, Almaty, Kazakhstan.
} 
the party system in Kazakhstan should develop' ${ }^{20}$ Additionally, a senior member of Asar noted that 'the decision was quite difficult to take, but a decision came from the top that said the party should be united'. ${ }^{21}$ This move was widely viewed as the 'minimisation of independent political forces ${ }^{22}$, in particular with regards to Nazarbayev's daughter, Dariga, who had set up Asar only in $2003 .^{23}$

Nur Otan was established simultaneous to a change in the constitution which rescinded the restriction on state representatives becoming members of political parties. This was an important step in binding in lower level elites and bureaucrats. This ensured stability for Nazarbayev not just with the high level informal networks which were influential, but also with government and state officials. Most important were the local Akims who not only became members but also chairmen of the regional branches of the party. ${ }^{24}$ The change in law allowed Nazarbayev to officially become leader of the party and consequently 'all officialdom was united under the party'. ${ }^{25}$ The signal from this legislation was that all state employees from government ministers to lower level bureaucrats should become members of the party. What has emerged is a relationship of dependency between state employees and the

\footnotetext{
${ }^{20}$ Interview with Azat Peruashev, former leader of GPK and current leader of Ak Zhol, 18 February 2007, Almaty, Kazakhstan.

${ }^{21}$ Interview with Bektas Mukhamedzhanov Member of Nur Otan Political Council and founding member of Asar, February 22, 2007 Almaty, Kazakhstan .

22 Interview with Marina Sabitova, OSDP Parliamentary Candidate, November 14 2006, Almaty.

23 After Asar was merged with Nur Otan Nazarbayeva was given the post of Vice President of Nur Otan. However, in 2007 she was removed from this position and denied a place on the party list for the 2007 parliamentary election. This demotion left her political ambitions in ruins.

${ }^{24}$ Akim Almaty sdelal svoi politicheskii vybor, www.zonakz.net, 26th June, 2007.

${ }^{25}$ Interview with Gani Alimovich Kaliev, Leader of the Social Democratic Party 'Auyl' (Village), 7 July 2011 Astana, Kazakhstan.
} 
party. When candidates are seeking a position within the states' employ there is a notional assumption between the applicant and the state institution that if accepting the position they will simultaneously join Nur Otan. Therefore, as noted by one analyst 'chiefly any person who holds a position in the government is obliged to become a member of the party' ${ }^{26}$ The party has become synonymous with civil servants and bureaucracy. Even one Nur Otan official noted that 'one of the ideas behind the party was to give jobs to many who were previously employed in the Communist Party'. ${ }^{27}$ The party's emergence has acted to synchronise the interests of the presidential administration and the state. The view of some analysts is that this means 'in principal Nur Otan is similar to the Communist Party of the USSR' ${ }^{28}$ However, Nur Otan does not possess the agency that benefited the CPSU. Nur Otan might benefit from the forcible encouragement of public officials to join the party when taking up their positions, but it is the state, and in particularly the influential Akims who have the purview and power to distribute the resources, positions and privilege, not the party. The party lacks creditability in terms of independent agency. It is seen as a tool of the state and an extension of the presidential administration. The party has no ideology or policy platform separate from Nazarbayev. For example, the party's 2007 election programme is based largely on the annual address the president gave earlier that year (Nur Otan, 2007). Hitherto, his personality and political outlook is reflected in everything about the party and how it acts.

Two questions arise from the above: is Nazarbayev's regime more stable vis-à-vis the instability caused through the competition between informal networks? And if so, did Nur Otan play a role in producing greater stability? It is difficult to prove unambiguously that Nur

\footnotetext{
${ }^{26}$ Interview with Pavel Lobachev, Director of NGO ‘Echo’ Elections and Democracy, Almaty, 14 July 2011.

${ }^{27}$ Interview with senior Nur Otan official, 8 May 2007, Almaty, Kazakhstan.

${ }^{28}$ Interview with Pavel Lobachev, Director of NGO ‘Echo’ Elections and Democracy, Almaty, 14 July 2011.
} 
Otan has played a role in providing stability vis-à-vis the fractious nature of competition between informal networks. Nonetheless, by using the party to tie in such high-level informal networks and broader groups of state officials, the outcome, at least in domestic terms has been a more stable and docile environment for the president. As highlighted above, perhaps one of the most influential networks of the late 1990s and early 2000s was the AlievNazarbayeva group. They have been effectively muzzled, with a large majority of their media and financial assets returning under state control and with both having their political ambitions of the presidency distinguished. Like Aliev, Mukhtar Ablayzov in 2009 fled abroad finding his interests in BTA Bank, the largest bank in Kazakhstan, taken over, forcibly he claims, by the state joint-stock company Samruk-Kazyna. An investigation committee of Kazakhstan's Interior Ministry has since indicted Ablayzov in absentia (Trifonov, 2010). Since the merger of the GPK into Nur Otan in 2006, analysts suggest Mashkevich has 'lost interest in politics'. ${ }^{29}$ In 2008 the mining company Kazakhmys, of which it is claimed Nazarbayev maintains control, raised its stake in ENRC to 26 per cent with Mashkevich reduced to only a 15 per cent stake (Global Witness, 2010). Moreover, Mashkevich has consistently had to deny rumours he is moving away from Kazakhstan for good (Absalyamov, 2011). Vladimir Ni passed away in 2010. While he was always a close confident of the president, working in the presidential administration during the 1990s, his wealth and alleged connections to media assets in the country made him a powerful and important figure in his own right (Plakhina and Dashov, 2007). The only senior elite figure with their own informal network to have survived the presidential concentration of power is Nazarbayev's second son-in-law, Timur Kulibayev. While Kulbayev retains access to his business interests in the energy industry, holds the important position of Chairman of

\footnotetext{
${ }^{29}$ Interview with political analyst, 14 July 2011, Almaty, Kazakhstan.
} 
Samruk-Kazyna and has been talked up as the potential successor to Nazarbayev, ${ }^{30}$ some analysts believe that 'in the present circumstances, Nazarbayev does not even trust his own family'. ${ }^{31}$ The implication is that Kulibayev and those associated with him, such as Prime Minister Karim Masimov, are not certain of their current favoured position. On one level Nur Otan was successful in dissipating the power of some of the powerful informal networks. The submergence of Nazarbayeva and Aliev's party Asar and Mashkevich's GPK is testament to that. Beyond the institutional merger of competing parties Nur Otan role has been limited. It was not responsible for the taking back under state management the financial and media resources once the preserve of these informal networks. Rather Nur Otan had a more important role in soliciting wider elite homogenisation throughout the synchronisation of the personalist regime with the state apparatus.

Beyond high-level competition between informal networks Nur Otan has helped stabilise and concentrate support for the regime. Due to its synchronisation with the state apparatus, such as local administrations, Nur Otan is guaranteed access to financial resources and a substantial base for electoral mobilisation. When Nur Otan emerged in 2006 it was claimed due to the merger with the other parties it would have a mass membership of over 1 million (Ivanov, 2006). Current estimates are much lower, for example, the Central Election Commission lists party membership as $607557 .{ }^{32}$ Whatever the true figure, due to its close association with the state apparatus the party possesses a large base of organisational support for electoral mobilisation. It has been implied that public employees and private business,

\footnotetext{
${ }^{30}$ Yermukhamet Yertysbaev: Timur Kulibayev - naibolee veroyatnyi preemnik glavy Kazakhstana, Ekspress K, 26 July 2011.

${ }^{31}$ Interview with Sergei Duvanov, political analyst, journalist, and activist, 9 September 2011, Almaty, Kazakhstan.

${ }^{32}$ See The Central Election Commission of Kazakhstan website, www.election.kz.
} 
under pressure from the local administration, encourage their subordinates to vote for Nazarbayev or Nur Otan in elections. According to Vladimir Kozlov, leader of the opposition party Alga, 'this forced voting was mostly common in the [student] dormitories where there was high dependence of the students on the administration.... The same situation was with the public employees and employees of those entrepreneurs whose heads are in close relationship with the authorities'. ${ }^{33}$ This organisational capacity was most effective in the 2007 parliamentary election where Nur Otan won 88.4 per cent of the vote and all seats in the Mazhilis and in the 2011 presidential election where the party's organizational capacity helped Nazarbayev achieve 95.5 per cent. Such election results and their preponderance over the political system creates both an aura of invincibility and inevitability around Nazarbayev's leadership which only acts to strengthen and stabilise his position and ensure a legislative imprimatur for any of his decisions.

The concentration of power, and the role of Nur Otan in that process, has minimised the instability of conflict between the informal networks underpinning the political system in Kazakhstan. Those actors and their informal group networks who previously were involved in an informal competition for resources and power have been marginalised and their political instruments, such as political parties dissolved or merged into Nur Otan. The party has been an important mechanism for forcing actors to accept the incumbent's leadership and relinquish their own political ambitions. It is difficult for executives to control and direct elite behaviour and a political party like Nur Otan can tie elites to the executive in a way that informal political groups (clan or regional factions) are not able to do. Furthermore, the case of Nur Otan exemplifies how parties as formal institutions can affect regime stability by securing and consolidating a wider support base of authoritarian rule through the

\footnotetext{
${ }^{33}$ Interview with Vladimir Kozlov, Chairman of Alga, 12 June 2011, Almaty, Kazakhstan.
} 
synchronisation of the party into the state apparatus. This enables the regime to utilise state resources and organisational capability to mobilise support through the proxy of a party

\section{Conclusion: Nur Otan and Regime Dynamics}

While Nur Otan does not provide the kind of benefits typically associated with dominant parties in authoritarian regimes, such as being the channel through which resources are distributed to co-opt opposition elites and potential challengers, the party provides a different kind of function for Nazarbayev. Nur Otan has acted to pacify the fall out resulting from competition between informal networks while also being an instrument for wider elite homogeneity through the synchronisation of the party and the state apparatus. The party has proved an effective mechanism through which to bind state elites and citizens employed within the public sector into the personalist regime of Nazarbayev. By being the party of the president, and by being supported by local executives, the regime has been able to rally support for the president by marrying peoples' commitment to their positions in the state sector to their membership of the party. While the party lacks independent agency (in the sense that it does not have policies or preferences separate from the president) this does not impinge on its capacity to act as this channel for providing support and stability for the regime among elites and workers in the state apparatus. This illustrates that in this case political parties have an important role to play even if we do not consider them genuine dominant or hegemonic parties such as the PRI in Mexico or the PAP in Singapore. Parties in authoritarian regimes do not necessarily just provide the functions and benefits proscribed in the existing literature regarding elite bargaining and cooption, and mass mobilisation. The case of Nur Otan has demonstrated they possess a function too in providing elite stability visà-vis informal politics. This is important as it suggests that in Kazakhstan formal institutions 
do have a role to play in a context in which informal networks, relations and decision-making processes are seen to dominate.

Two questions remain outstanding. Can Nur Otan continue to provide elite stability? And what does the party tell us about the relationship between formal and informal politics in post-Soviet Central Asia? While Geddes has suggested that one party regimes last longer than authoritarian regimes which do not use a political party, Nur Otan and the case of Kazakhstan are different from many examples of dominant parties in authoritarian regimes. A personalist authoritarian regime exists in Kazakhstan in which the party has no agency independent from the president. The party was set up to represent the interests, preferences and policies of Nazarbayev. It lacks autonomy and this assists in explaining why the party does not provide the same benefits and functions of parties in dominant party regimes such as the PAP. This dependency on Nazarbayev for its raison d'être goes some way to addressing the question of whether the party can continue to maintain this role in providing elite stability. As long as Nazarbayev remains then perhaps so will the party. However, many observers in Kazakhstan feel that it is unlikely Nur Otan will survive once Nazarbayev leaves the political scene. The belief is that any chance the party has of longevity beyond the Nazarbayev era depends entirely on the attitude of the president's successor. ${ }^{34}$ This does not address the question of whether it could continue to play a role of assisting with elite stability vis-à-vis informal politics, and perhaps that is not a question which can be answered definitively. Nonetheless, it is evident that party is inextricably tied to Nazarbayev and that once those personalist bonds are removed any shred of authority and legitimacy the party has will be deeply contested. Likewise the party's ability to sustain elite stability and cohesion in the upper

\footnotetext{
${ }^{34}$ Interviews with Yuri Buluktaev, Academy of Sciences, $16^{\text {th }}$ 2011September, Almaty, Kazakhstan and Sergei Duvanov, political analyst, journalist and activist, 9 September 2011, Almaty, Kazakhstan
} 
echelons of the elite and their utility in synchronising the personalist regime with the state apparatus will most likely diminish. Citizens and employees within the state sector will feel less obliged to take up party membership as the party would no longer be guaranteed its preeminent standing given its patron is no longer in a position of power. It illustrates that the party's position and ability to provide elite stability is contingent upon regime dynamics.

This article has illustrated that formal institutions can have an important and perhaps meaningful role in Kazakhstan, and that formal institutions are not necessary pervaded or circumscribed persistently by informal institutions and organisations as is implied in much of the literature on the region. The case of Nur Otan has demonstrated that a formal institution can act to stabilise the unstable nature of competition between informal networks. In this case informal institutions are not competing with a formal institution, neither are they substituting for defects within a formal institution and nor in this case is the relationship between the formal and informal an accommodating one. Rather for Nazarbayev's personalist authoritarian regime, Nur Otan as a formal institution complements the informal networks which underpin his power by proffering stability when they have tended towards instability. However, the informal networks remain important to the president as his authority depends on his ability to distribute resources between them, and perhaps explains why even after the consolidation of his power some groups continued to prosper, such as Timur Kulibayev's network.

The case of Nur Otan has been revealing in terms of what it can tell us about the nature of political parties and formal institutions, and the relationship between the formal and informal, in personalist authoritarian regimes. However, the insights it provides are only partial and this article is a useful departure point for further comparative research which can widen the scope 
in examining the role, function and benefits parties can provide rulers in personalist authoritarian regimes in the former Soviet space. Moreover, as stated at the beginning of the article, the role of Nur Otan in Kazakhstan does bring into question the dichotomy between the formal and informal. The fact that many analysts in Kazakhstan cannot see the party surviving beyond the political career of Nazarbayev, emphasises not only the lack of agency the party has, but also the extent to which it exists as a separate formal institutional entity independent of the personalised power of the president. The usual barometer of defining formal institutions is their embodiment of impersonalised rationalism, but in the case of Kazakhstan it is clear that while on the surface the party is a formal institution, underneath its operation and political success is defined by the personalised power of the president. In addition, given the party performs a function to complement elite instability, driven by factional informal competition, it only lends itself to heightening the lack of conceptual clarity between the formal and informal in this case. While it might not be the case that there is a lack of clarity in all instances of interaction between what we consider formal and informal politics, the case of Nur Otan illustrates that we do have to navigate this conceptual dichotomy with trepidation and not fall into its elegant and parsimonious trap. Indeed, there may be value in political scientists re-visiting our conceptual understanding of what constitutes the formal and informal in the future.

\section{References}

Absalyamov, N. (2011) Aleksandr Mashkevich: 'Ya Nikuda ne ukhozhu I nichego ne prodayu', Ekspress $K, 14$ September. 
Adilov, M. (2007) Vse vozvrashchaetsya na krugi svoya? Respublika, 6 July.

Ake, C. (1975) A Definition of Political Stability, Comparative Politics, 7, (2): 71-283

Ayaganov, B. G., Baimagambetov S. Z., and Zhumanova, G. Zh. (1994) Politicheskie partii i obshchestvennye dvizheniya sovremennogo Kazakhstana spravochnik vypuski 1 (Almaty, TUDAP).

Babak, Vladimir, Vaisman, Demian and Wasserman, Aryeh, Political Organisation in Central Asia and Azerbaijan: Sources and Documents, (London, Frank Cass, 2004).

Blaydes, L. (2011) Elections and Distributive Politics in Mubarak's Egypt, (New York: Cambridge University Press).

Borisova, E. A. (2005) Kazakhstan prezident i vneshiaya politika, (Moscow, Natalis).

Borocz, J. (2000) 'Informality Rules', East European Politics and Societies, 14.

Bratton, M. (2007) Formal Versus Informal Institutions in Africa, Journal of Democracy, 18 (3): 96-110.

Brownlee, J. (2007) Authoritarianism in the Age of Democratisation (Cambridge, Cambridge University Press). 
Buluktaev, Y., D’iachenko, S. and Karmazina, L. (1998) Politicheskie Partii Kazakhstana Spravochnik 1998 (Almaty, IPK).

Chebotarev A. (2006) 'Politicheskii krizis oseni 2001 goda I ego pocledstviya: 5 let spustya' 7 November. Online. Available HTTP: http://www.kub.kz/article.php?sid=15070 (accessed 9 November 2006).

Collins, K. (2006) Clan Politics and Regime Transition in Central Asia, (Cambridge: Cambridge University Press).

Cummings, S. (2000) Kazakhstan: Centre-Periphery Relations (London, Royal Institute of International Affairs).

Cummings, Sally N. (2005), Kazakhstan: Power and the Elite (London: I.B. Tauris).

Duvanov, S. (2007) Est' Situatsii Kogda Grazhadanskii dolg stanovitsya grazhdanskoi obyazannost'u, 24 May. Online. Available HTTP: http://www.kub.kz/article.php?sid=17591(accessed 24 May 2011).

D’yachenko, S., Karmazina L. and Seidumanov, S. (2000) Politicheskie partii Kazakhstana god 2000 spravochnik. (Almaty: Information-Analitical Centre of the Parliament of Kazakhstan). 
ECPRAST (Eurasian Centre of Political Research and the Agency for Social Technologies) (2005), 'Gruppy vliyaniya vo vlastno-policheskoi sisteme Respubliki Kazakhstan', November 2005. (Almaty and Moscow).

Fumagalli, M. (2007) Informal Ethnopolitics and Local Authority Figures in Osh, Kyrgyzstan, Ethnopolitics, 6 (2): 211-233.

Gallina N. (2011) Beyond Democracy: The Relevance of Informal Power in Eastern Europe, in: Hayoz, Nicolas and Leszek Jesien (eds.), 1989 in Central and Eastern Europe: Implications and Meanings Twenty Years later. (Bern: Peter Lang) .

Gandhi J. 2008. Political Institutions under Dictatorship.(Cambridge, UK: Cambridge Univ. Press).

Gandhi J, Przeworski A. 2006. Cooperation, cooptation, and rebellion under dictatorships. Economics and Politics. 18 (1): 1-26.

Geddes, B. (2003) Paradigms and Sand Castles: Theory Building and Research Design in Comparative Politics.(Ann Arbor, The University of Washington Press).

Geddes B. (2006) Why parties and elections in authoritarian regimes? Presented at Annu. Meet. Am. Polit. Sci.

Assoc.,Washington, DC 
Global Witness (2010) Risky Business: Kazakhstan, Kazakhmys PLC and the London Stock Exchange, Global Witness Report July 2010.

Grosin, A. (2005) Kto est kto v sovremenom Kazakhstane. Zanimatel'no - o klanovykh gruppirovkakh (Moscow, Instituta Stran SNG).

Grosin, A. (2006) Kazakhstan na puti k sozdanyu "partii partii”, RIA-Novosti, 6 July 2006. Online. Available HTTP: http://ria.ru/analytics/20060706/50980499.html.

Grzymala-Busse, A. (2010) The Best-Laid Plans: The Impact of Informal Rules on Formal Institutions in Transitional Regimes, Studies in Comparative International Development, 45 (3): 311-333.

Guasti, P. and Dobovsek, B. (2011) Informal Institutions and EU Accession: Corruption and Clientelism in Central and Eastern Europe, Paper presented at ECPR General Conference in Reykjavik, August 2011.

Gulette, D. (2007) 'Theories on Central Asian Factionalism: The Debate in Political Science and its Wider Implications', Central Asian Survey, 26, 3: 373- 87.

Hall, P. and Taylor, R. (1996) 'Political Science and the Three New Institutionalisms' Political Studies, 44, 5: 936-57.

Helmke, G. and Levitsky, S. (2006) Informal Institutions and Democracy (Baltimore, John Hopkins University Press). 
Helmke, G. and Levitsky, S. (2003) Informal Institutions and Comparative Politics: A Research Agenda, Working Paper \#307 - September 2003.

Hough, J. and Fainsod, M. (1980) How the Soviet Union is Governed.(Cambridge: Harvard University Press).

Ilkhamov, A. (2007) Neopatrimonialism, Interest Groups and Patronage Networks: the impasses of the governance system in Uzbekistan, Central Asian Survey, 26, 1: 65-84.

Isaacs, R. (2011) Party System Formation in Kazakhstan: Between Informal and Formal Politics. (London, Routledge).

Isaacs, R (2010) Informal Politics and the Uncertain Context of Transition: Revisiting Early Stage Non-Democratic Development in Kazakhstan, Democratization, 17, 1: 1-25.

Isaacs, R. (2008) 'Managing Dissent, Limiting Risk and Consolidating Power: The Processes and Results of Constitutional Reform in Kazakhstan', Central Asia and the Caucasus, 44, 1: $16-25$.

Ishiyama, J. (2002) Neopatrimonialism and the Prospects for Democratization in the Central Asian Republics, in Sally N. Cummings (ed.) Power and Change in Central Asia. (London, Routledge): 42-58. 
Ishiyama, J. (2008) Political Party Development and Party "Gravity" in Semi-authoritarian States, Taiwan Journal of Democracy, 4, 1:33-53.

Ivanov, I. (2006) Odin million soldat 'Otana' Grazhdanskii i Agrarnye partii (nabory) Kazakhstana izmereny (sobirayas') slivat'sya s 'Otanom', Kanal 31, $23^{\text {rd }}$ October 2006.

Jones Luong, P. (2002) Institutional Change and Political Continuity in Post-Soviet Central Asia: Power, Perceptions, and Pacts (Cambridge, Cambridge University Press).

Junisbai, B. and Junisbai, A. (2005) 'The Democratic Choice of Kazakhstan: A Case Study in Economic Liberalization, Intra-elite Cleavage, and Political Opposition', Demokratizatsiia, 13, 3:373-92.

Junisbai, B. (2010) A Tale of Two Kazakhstans: Sources of Political Cleavage and Conflict in the Post-Soviet Period, Europe-Asia Studies, 62, 2: 235-69.

Kadyrov, S. (2007) Antologiya Kazakhskikh elit chast' vtoraya: clany reshaiut vse, www.kub.info, 9 September, Online. Available HTTP:http://www.kub.info/article.php?sid=19254 (accessed 10 September 2007).

Kaernet, H., Satpayev, D. and Torjesen, S. (2008) Big Business and High Level Politics in Kazakhstan: An Everlasting Symbiosis? China and Eurasia Quarterly, 6, 1: 99-101.

Khabieva A. (2011) V Akmolinskoi oblasti osudili eks-akima Esil'kogo raiona, www.nomad.su, 9 August, http://www.nomad.su/?a=13-201108100005. 
Khlyupin, V. N. (1998) Bol'shaya Sem'ya Nursultana Nazarbayeva: Politicheskaya elita sovremennogo Kazakhstana (Moscow, Institute for Contemporary Political Research).

Khlyupin, V. N. (2000) Kazakhstanskaya politicheskaya elita mezhdu modernizatsiei i traibalizom, Report to the Second All-Russian Congress of Political Scientists, Moscow MGIMO, 22 April. Online. Available HTTP:

http://www.iicas.org/page.php?c=publrus\&id=105 (accessed 12 January 2007).

Kitschelt H. and Wilkinson, S. I. (2007) (eds.) Patrons, Clients and Policies: Patterns of Democratic Accountability and Political Competition. (New York, Cambridge University Press).

Koehler, K. (2008) Authoritarian Elections in Egypt: Formal Institutions and Informal Mechanisms of Rule, Democratization, Vol.15, No.5, December 2008, pp.974-990.

Konstitutsiia Respubliki Kazakhstan 1995 (2006) (Almaty, Yurist).

Lauth, H. (2000) Informal Institutions and Democracy, Democratization, 7 (4): 21-50.

Lauth, H. (2004) Formal and Informal Institutions: Structuring their Mutual Co-existence, Romanian Journal of Political Science, 4 (1): 66-88.

Law on Political Parties (2002) Zakon Respubliki Kazakhstan o politicheskikh partiiakh ot 15 Iulia 2002. 
Lust-Okar, Ellen, Structuring Conflict in the Arab World: Incumbents, opponents and institutions (Cambridge, Cambridge University Press, 2005).

Magaloni, B. and Kricheli, R. (2010) Political Order and One-Party Rule, The Annual Review of Political Science, 13: 123-143.

Magaloni, B. (2008) Credible Power Sharing and the Longevity of Authoritarian Rule, Comparative Political Studies, 41 (4/5): 715-745.

Massanov, N. (2000) Political Elite in Kazakhstan: The Changes of Kazakhstani Political Elite During the Period of Sovereignty, International Eurasian Institute for Economic and Political Research, Almaty. Online. Available HTTP: http://iicas.org/english/publ_22_11_00.htm (accessed 14 November 2006).

Melvin, N. (2004) 'Authoritarian Pathways in Central Asia: A Comparison of Kazakhstan, the Kyrgyz Republic and Uzbekistan', in Yaacov Roi’ (ed.), Democracy and Pluralism in Muslim Eurasia (London, Frank Cass: 119-42).

Millet, K. (2000) [1969] Sexual Politics. (Chicago: University of Illinois Press).

Nazarbayev, N. (2007) Novyi etap demokratizatsii Kazakhstana - uskorpennoe razvitie svobodnogo Demokraticheskogo, www.akorda.kz, 16 May. Online. Available HTTP: http://www.kub.kz/print.php?sid=17456 (accessed 19 May 2007). 
Nur Otan (2007) Za protsvetanie Kazakhstana i blagopoluchie Kazakhstantsev (Astana, Nur Otan).

Nomad.su (2008) Mazhilis: V den' gosudarstvennykh simvolov palatoi odobrena popravka v konstititsionnyi zakon, $\underline{w w w . n o m a d . s u} 4$ July. Online. Available HTTP: http://www.nomad.su/?a=3-200806050425 (accessed 04 July 2008).

North D.C. (1990) Institutions, Institutional Change and Economic Performance, New York, Cambridge University Press

O’Donnell, G. (1996) 'Illusions about Consolidation, Journal of Democracy, 7, 2: 34-51.

Olcott, M. B. (2002) Kazakhstan Unfulfilled Promise (Washington, Brookings Institution Press).

Plakhina, Y., and Dashov, D. (2007) Kto on, Vladimir Ni?, www.freeas.org, 8 June 2007, Online. Available HTTP: http://www.freeas.org/?nid=7215

Press Service of RNPK (2001), Zaochnyi sud nad Kazhegeldinym kak rezul'tat politiki $\begin{array}{llllll}\text { bezzakoniya } & i & \text { proizvola, } & 7 & \text { September }\end{array}$ http://kazhegeldin.addr.com/articles/About_07_09_01_3.htm [accessed 26.06.2008].

Pempel T.J, ed. 1990. Uncommon Democracies. (Ithaca, NY: Cornell Univ. Press). 
Radnitz, S. (2011) Informal Politics and the State, Comparative Politics, April 2011, 43 (3): $351-371$

Radnitz, S. (2005) Networks, Localism and mobilisation in Asky, Kyrgyzstan, Central Asian Survey, Vol. 24 No. 4, pp. 405-424.

Robinson, N. (2007) 'The Political is Personal: Corruption, Clientelism, Patronage, Informal Practices and the Dynamics of Post-Communism', Europe-Asia Studies, 59, 7: 1217-1224.

Satpayev, D. (2007) ‘An Analysis of the Internal Structure of Kazakhstan’s Political Elite and an Assessment of Political Risk Levels', in Uyama Tomohiko (ed.) Empire, Islam and Politics in Central Eurasia (Sapporo, Slavic Research Center Hokkaido University): 283300.

Satpayev, D. (1999) Lobbizm: Tainye Rygachi. (Vlasti. Almaty).

Schatz, E. (2004) Modern Clan Politics and Beyond: The Power of "Blood" in Kazakhstan (Seattle and London, University of Washington Press).

Serdalina, Z. (2001) 'Biznes-elita pozhalovalas' prezidentu', Komsomol'skaya Pravda, 1 November. Online. Available HTTP: http://www.kub.info/article.php?sid=211 (accessed 4 May 2007).

Starr, F. (2006) Clans, Authoritarian Rulers and Parliaments in Central Asia, Silk Road Paper, Washington D.C., Central Asia-Caucasus Institute and Silk Studies Program. 
SPK (1992) Programma Sotsialisticheskoi partii Kazakhstana. (Almaty: Proket).

Stefes, C. H. (2006) Understanding Post-Soviet Transitions: Corruption, Collusion and Clientelism (Basingstoke, Palgrave Macmillan).

Suttner, R. (2006) Party Dominance 'Theory': Of What Value? Politikon, (December 2006), 33(3), 277-297.

Taylor, M., (1992) Formal Versus Informal Incentive Structures and Informal Behaviour, Journal of Politics, 52.

Thelen, K. \& Steinmo, S. (1992) 'Historical Institutionalism in Comparative Politics' in Sven Steinmo, Kathleen Thelen and Frank Longstreth (eds.) Structuring Politics: Historical Institutionalism in Comparative Analysis. (Cambridge, Cambridge University Press): 1-32.

Trifonov, V. (2010) Kazakhskomu baniru nashchli delo v Rossii, Kommersant 5 July.

Tunçer-Kilavuz (2009) Political and social networks in Tajikistan and Uzbekistan: 'clan', region and beyond, Central Asian Survey, 28 (3): 323-334. 
Weber, M. (1978) Economy and Society, Edited by Guenther Roth and Claus Wittich (Berkley, University of California Press).

Wedel, J. (2005), 'Flex Organising and the Clan-State: Perspectives on Crime and Corruption in the New Russia', in Pridmore, A (ed), Ruling Russia: law, Crime and Justice in a Changing Society. (Lanham, MA and Oxford: Rowan and Littlefield):101-116.

Wilson, A. (2005) Virtual Politics: Faking Democracy in the post-Soviet World, (Yale, Yale University Press).

Wintrobe, R. (1998) The Political Economy of Dictatorship. (Cambridge: Cambridge University Press).

Yuritsyn, V. (2004) Problema nepravnykh uslovii v finacyrovanii politicheskikh partii Kazakhstana, in Andrei Chebotarev, Serei Elomnikov and El'vira Pak (eds.), Voprosy prozrachnosti deiatel'nosti politicheskikh partii i ikh vzaimodeistviia s institutami vlasti biznesa i obshchestva: kazakhstanskii i zarubezhnyi opyt, (Almaty, Transparency Kazakhstan): 38-41. 